\title{
Studi Eksploratif Mengenai Yogyakarta sebagai Pengirim Wisatawan Keluarga
}

\author{
Wardiyanta ${ }^{1}$ \\ Sudarmadji ${ }^{2}$ \\ Nopirin $^{3}$
}

\begin{abstract}
Family recreation is becoming more popular among families in Yogyakarta. This phenomenon is associated with an increased understanding of the importance of family togetherness, strengthen family ties and family memories. The practice of family recreation is affected by geographic, demographic changes, and understanding of the importance of tourism for the family. The purpose of this study is to explain the tendency of families's understanding of family recreation and trend of family recreation. The findings suggest that family recreation associated with increased understanding and mobility of families. This study contributes to an understanding of the social changes in Yogyakarta families and its meaning for the tourism industry in the future.
\end{abstract}

Keywords:

family recreation; mobility; demographic.

\begin{abstract}
Abstrak
Rekreasi keluarga semakin populer di kalangan keluarga di Yogyakarta. Fenomena tersebut terkait dengan meningkatnya pemahaman mengenai pentingnya kebersamaan keluarga untuk memperkuat ikatan keluarga. Pelaksanaan rekreasi keluarga dipengaruhi oleh kondisi geografi, perubahan demografi dan pemahaman masyarakat terhadap pentingnya pariwisata bagi keluarga. Tujuan penelitian ini adalah menjelaskan kecenderungan pemahaman tentang rekreasi keluarga oleh keluarga di Yogyakarta. Selain itu juga membahas kecenderungan perkembangan rekreasi keluarga. Temuan menunjukkan rekreasi keluarga terkait dengan meningkatnya pemahaman dan mobilitas keluarga. Penelitian ini memberikan sumbangan pada pemahaman tentang perubahan sosial yang terjadi pada keluarga di Yogyakarta dan maknanya bagi industri pariwisata di masa mendatang.
\end{abstract}

\section{Kata Kunci:}

rekreasi keluarga; mobilitas; demografi.

\section{Pendahuluan}

Minat masyarakat Yogyakarta terhadap rekreasi keluarga tinggi, namun Yogyakarta bukan menjadi pilihan utama untuk berekreasi keluarga, terutama bagi keluarga kelas menengah dan atas. Hal itu dapat dilihat dari banyaknya masyarakat Yogyakarta yang berekreasi bersama keluarga dengan

\footnotetext{
${ }^{1}$ Dosen Politeknik Akademi Pariwisata Indonesia Yogyakarta

Email: wardiyanto_ad@yahoo.com.

${ }^{2}$ Guru Besar Fakultas Geografi UGM

${ }^{3}$ Guru Besar Fakultas Ekonomika dan Bisnis UGM
} 
mengunjungi berbagai objek wisata keluarga di luar Yogyakarta bahkan di luar negeri (Tabel 3). Fenomena itu memiliki dua makna, di satu sisi masyarakat memiliki kemampuan ekonomi untuk membiayai rekreasi keluarga, di sisi lain menunjukkan adanya kendala untuk berekreasi keluarga di Yogyakarta. Kenyataan itu menjadikan Yogyakarta bukan sebagai tujuan wisata tetapi juga sebagai pengirim wisatawan.

Rekreasi keluarga merupakan fenomena sosial yang terjadi karena dinamika perubahan demografi dan struktur sosial (Schanzel et al., 2012). Rekreasi keluarga dipandang memiliki banyak manfaat, bagi pribadi maupun bagi keluarga. Bagi pribadi, rekreasi berguna untuk menghabiskan waktu dari tuntutan pekerjaan (Schanzel et al., 2012), sedangkan bagi keluarga, rekreasi keluarga menjadi salah satu sarana yang digunakan untuk memperkuat ikatan keluarga dan sebagai sarana pendidikan anak.

Besarnya potensi Yogyakarta sebagai pengirim wisatawan dipengaruhi oleh dua faktor, yakni internal dan eksternal. Sisi internal, Yogyakarta berada pada posisi strategis, di bagian tengah pulau Jawa sehingga jarak ke kota-kota lain di sekitarnya relatif dekat. Yogyakarta memiliki penduduk yang banyak sehingga banyak pula keluarga yang memiliki kemampuan berekreasi. Telah terjadi perubahan pada masyarakat, antara lain 1) perubahan pandangan mengenai rekreasi, berekreasi dinilai sebagai hal yang positif; 2) peningkatan kesejahteraan, sehingga sebagian besar keluarga memiliki kemampuan untuk berekreasi; 3) perubahan perilaku konsumsi masyarakat sebagai akibat dari terjadinya globalisasi dan 4) meningkatnya permintaan wisata, keterbatasan kapasitas dan kualitas objek serta daya tarik wisata yang ada di Yogyakarta sehingga tidak mampu memenuhi kebutuhan masyarakat untuk berekreasi. Faktor lainnya adalah tersedianya prasarana dan sarana pendukung pariwisata yang memudahkan masyarakat untuk melakukan perjalanan wisata, antara lain sarana komunikasi, sarana akomodasi dan sarana transportasi.

Faktor eksternal yang berperan antara lain 1) munculnya kebijakan pemerintah yakni Keputusan Bersama tentang Hari Libur Nasional dan Cuti Bersama yang mulai berlaku akhir tahun 2002. Keputusan itu merupakan realisasi komitmen pemerintah pada pengembangan dunia pariwisata nasional dengan mendorong pengembangan pergerakan pasar wisatawan domestik ${ }^{4}$. Kebijakan itu sangat berarti bagi perkembangan pariwisata karena dapat mendorong keluarga, khususnya para pegawai negeri untuk melakukan perjalanan memanfaatkan hari libur panjang untuk melakukan rekreasi atau berwisata; 2) banyaknya penawaran pariwisata dari daerah tujuan wisata di sekitar Yogyakarta sebagaimana promosi yang dapat disaksikan melalui media cetak maupun elektronik. Kini banyak daerah mengembangkan pariwisata, mereka semakin aktif dan intensif menawarkan produk wisata serta melengkapi dirinya dengan berbagai sarana pendukung pariwisata sehingga wisatawan menjadi tertarik dan mendapatkan kemudahan untuk berkunjung.

Berdasarkan uraian tersebut maka penelitian ini menelaah "kondisi yang menjadikan Yogyakarta selain sebagai tujuan wisatawan, juga sebagai daerah yang berpotensi sebagai pengirim wisatawan keluarga." Kondisi sosial ekonomi dan budaya masyarakat Yogyakarta yang dinamis merupakan fenomena yang cukup menarik dan relevan untuk dikaji.

\section{Rekreasi Keluarga}

Rekreasi Keluarga dapat memberikan pengalaman keluarga yang positif untuk orang tua dan anak-anak (Elliot, 2010). Rekreasi keluarga adalah komitmen orang tua, yang diatur dan dipersiapkan untuk kepentingan

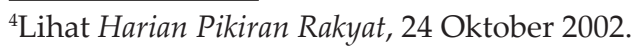


anak-anak dan keluarga secara keseluruhan (Shaw, 2008). Orang tua selalu berpikir tentang manfaat yang diperoleh anak-anak dari partisipasinya pada rekreasi keluarga, jadi anak-anak menjadi prioritas utama dalam pembuatan keputusan rekreasi. Selain itu, orang tua menggunakan rekreasi keluarga untuk menunjukkan kepada anak-anak mereka pengertian dan rasa memiliki keluarga serta kehidupan keluarga dan pengasuhan yang baik (Shaw, 2008).

Hornig (2006) menyebut rekreasi keluarga sebagai rekreasi bersama, yaitu dalam setiap kegiatan rekreasi, semua anggota keluarga berpartisipasi. Pelaku kegiatan rekreasi keluarga adalah keluarga sebagai sebuah institusi. Mengenai tempat pelaksanaannya, Shaw dan Dawson (2001) menjelaskan bahwa rekreasi keluarga bisa dilakukan di luar rumah (outdoor recreation) atau di dalam rumah (indoor recreation). ${ }^{5}$ Melalui pembatasan tersebut, maka rekreasi keluarga disebut purposive leisure yakni rekreasi yang tujuan pokoknya bukannya bersenang-senang semata, tetapi memiliki tujuan lain yang lebih bermanfaat bagi anak-anak (Shaw dan Dawson, 2001). Definisi tersebut untuk menggambarkan upaya orang tua dalam membuat, mengatur, memfasilitasi dan memberikan pengalaman rekreasi bersama yang "bermanfaat" untuk mencapai tujuan yang diharapkan oleh orang tua, yakni memperkuat ikatan keluarga dan memberikan kesempatan pada anak untuk belajar tentang nilai-nilai kehidupan. Purposive leisure dapat dipandang sebagai sebuah konsep untuk mengamati dan memahami motivasi orang tua dan pilihan keluarga dalam berekreasi. Orang tua menyandingkan harapan mereka pada rekreasi keluarga dengan pengalaman itu sendiri.

\footnotetext{
Pada studi ini, rekreasi keluarga menunjuk pada rekreasi di luar rumah dan sering disebut berwisata. Rekreasi di rumah (in door recreation) tidak dibahas lebih lanjut karena tidak terkait dengan pariwisata.
}

\section{Manfaat Rekreasi Keluarga}

Rekreasi keluarga berperan positif dalam meningkatkan kohesi keluarga, menjaga stabilitas perkawinan, meningkatkan hubungan keluarga dan meningkatkan kualitas keluarga secara keseluruhan. Beberapa penelitian menjelaskan hubungan positif antara partisipasi rekreasi dengan keberhasilan keluarga (Freeman dan Zabriskie, 2003; Shaw dan Dawson, 2001; Mannell dan Kleiber, 1997). Salah satu yang paling penting adalah manfaat rekreasi keluarga bagi pendidikan anak-anak. Rekreasi keluarga memungkinkan anak-anak memperoleh keterampilan dalam arena sosial dan membantu untuk mengembangkan minat mereka dalam rekreasi. Mannell dan Kleiber (1997) menyebutkan bahwa rekreasi keluarga dapat digunakan sebagai sarana untuk mengarahkan perkembangan anak. Orang tua secara sadar dan sengaja merencanakan dan memfasilitasi kegiatan-kegiatan rekreatif untuk membantu mengembangkan rasa keluarga dan membantu anggota keluarga menjadi lebih dekat satu sama lain, serta mengajarkan anggota keluarga tentang nilainilai dan pelajaran hidup (Shaw dan Dawson, 2001).

Rekreasi keluarga juga memberikan kesempatan kepada anak-anak memperoleh keterampilan sosial. Banyak kegiatan rekreasi dilakukan dalam format kolektif yang memungkinkan peserta untuk mendapatkan teman dan menumbuhkan semangat (jiwa) kekeluargaan (Iwasaki dan Havitz, 1998). Banyak program rekreasi keluarga memerlukan kegiatan interaktif yang mendorong komunikasi intra famili dan mempromosikan sosialisasi kepada anak (Horna, 1989). Bermain bersama membutuhkan kerjasama antara orangtua dan anak. Akibatnya, memungkinkan anakanak belajar bergaul dengan orang lain, berbagi sumber daya dan informasi, serta mempertahankan loyalitas kepada keluarga (Smith, 1997). 


\section{Metode Penelitian}

Penelitian ini menggunakan desain penelitian mixed method, menggabungkan metode kuantitatif dan kualitatif dalam mengumpulkan, menganalisis dan memadukan hasil kajiannya (Johnson dan Onwuegbuzie, dalam Damanik dkk, 2012). Pendekatan ini dipilih karena penelitian berkaitan dengan kompleksitas pemahamanmasyarakatmengenai kehidupan sosial yang mengelilinginya. Hasil survei kemudian didalami lewat wawancara yang pertanyaannya dibingkai oleh teori dan konsep psikologi, sosial dan budaya sebagai titik acuannya.

Survei dilaksanakan dengan menggunakan kuesioner untuk menggali wawasan awal responden tentang topik rekreasi keluarga. Selanjutnya, wawancara secara mendalam dilaksanakan terhadap informan untuk mengonfirmasi hasil kuesioner dan memberikan konteks pemahaman mereka secara lebih luas tentang rekreasi dan segala hal yang terkait. Pada saat wawancara, peneliti memberi kesempatan kepada informan untuk menjelaskan pemahaman mereka mengenai rekreasi dan hal-hal yang mendorongnya berekreasi bersama keluarga. Selanjutnya peneliti mendorong informan untuk membangun pemahaman mereka sendiri.

Penelitian ini menggunakan data primer dari responden kepala keluarga yang diambil dari sampel keluarga di Yogyakarta ${ }^{6}$ yang dalam lima tahun terakhir $(2008,2009,2010$, 2011, 2012) berekreasi bersama anggota keluarga ${ }^{7}$. Data sekunder berupa data statistik dan hasil studi terkait dengan kegiatan rekreasi keluarga yang dilaksanakan oleh keluarga Yogyakarta digunakan untuk melengkapi data

\footnotetext{
${ }^{6}$ Sampel keluarga yang dipilih adalah keluarga yang memiliki anak kelompok usia anak-anak dan remaja, bagi yang anaknya sudah dewasa tidak dipilih karena biasanya anaknya sudah mempunyai pilihan sendiri dalam berekreasi.

7 Keluarga yang dijadikan responden adalah keluarga yang memiliki pengalaman melaksanakan rekreasi keluarga, minimal sekali dalam satu tahun.
}

primer. Penelitian ini menggunakan teknik pengambilan sampel multistage random sampling yang dilakukan melalui cluster karena tujuan penelitian adalah menjaring sebanyak mungkin informasi dari berbagai sumber yang memiliki akses informasi mengenai permasalahan yang diteliti. Data dianalisis dengan perangkat lunak paket statistik SPSS 15.0 yang mencakup analisis deskriptif maupun inferensial. Analisis regresi digunakan untuk mengetahui hubungan antara pemahaman terhadap pariwisata dan manfaatnya dengan pengambilan keputusan keluarga untuk berwisata bersama keluarga.

\section{Yogyakarta sebagai Daerah Tujuan Wisata dan Pasar Wisatawan}

Pada peta kepariwisataan Indonesia, Yogyakarta adalah daerah tujuan wisata utama kedua setelah Bali ${ }^{8}$. Yogyakarta memiliki potensi daya tarik wisata yang kuat, diantaranya 1) memiliki objek wisata yang sangat beragam, 2) memiliki beragam kerajinan yang dapat dijadikan cinderamata, 3) memiliki sumber daya manusia berkualitas, dan 4) industri kreatif yang menjadi pendukung pariwisata berkembang dengan baik. Selain itu didukung oleh keberadaan sarana pendukung pariwisata yang mencukupi. Kondisi tersebut memperkuat daya tarik Yogyakarta sebagai destinasi wisata baik bagi wisatawan nusantara maupun mancanegara. Lima tahun terakhir, wisatawan nusantara yang berkunjung ke Yogyakarta meningkat hampir 300 persen dari tahun 2008 (Tabel 1).

Banyaknya wisatawan yang datang di Yogyakarta memiliki dua akibat atau dampak yang berpotensi positif dan negatif. Satu sisi positif, yakni membawa manfaat ekonomi yang dapat dinikmati masyarakat, sementara dari sisi sosial budaya bisa tidak menguntungkan, bahkan merugikan. Budaya modern yang dibawa wisatawan, berpotensi bertentangan

\footnotetext{
8 "Peranan Objek Wisata dalam Perkembangan Kepariwisataan Daerah Istimewa Yogyakarta" dalam http://sosiopage.blogspot.co.id/2012/01/peranan-objekwisata-dalam-perkembangan.html.
} 
Tabel 1.

Perkembangan wisatawan yang berkunjung ke DIY (2008 - 2012)

\begin{tabular}{ccccc}
\hline Tahun & $\begin{array}{c}\text { Wisatawan } \\
\text { mancanegara }\end{array}$ & Pertumbuhan (\%) & $\begin{array}{c}\text { Wisatawan } \\
\text { nusantara }\end{array}$ & Pertumbuhan (\%) \\
\hline $\mathbf{2 0 0 8}$ & 128.660 & 24,64 & 1.156 .097 & 0,86 \\
$\mathbf{2 0 0 9}$ & 139.492 & 8,42 & 1.286 .565 & 11,29 \\
$\mathbf{2 0 1 0}$ & 140.700 & 0,87 & 2.851 .000 & 121,60 \\
$\mathbf{2 0 1 1}$ & 148.800 & 5,76 & 3.057 .600 & 7,25 \\
$\mathbf{2 0 1 2}$ & 148.500 & $-0,21$ & 3.398 .500 & 11,15 \\
\hline
\end{tabular}

Sumber: diolah dari Statistik Pariwisata DIY 2013

dengan nilai-nilai positif kehidupan masyarakat. Selain itu, dengan kapasitas daya tampung yang terbatas, banyaknya wisatawan membuat kondisi objek wisata menjadi tidak menyenangkan penduduk setempat. Hal itu bisa mempengaruhi keputusan masyarakat Yogyakarta untuk berekreasi di luar Yogyakarta.

Yogyakarta memiliki beragam potensi budaya, objek dan daya tarik wisata (ODTW) serta kesiapan dalam hal sarana penunjang kegiatan pariwisata dan industri pendukung kegiatan kepariwisataan, antara lain transportasi, akomodasi, restoran dan rumah makan, industri souvenir serta Biro Perjalanan Wisata (BPW). Dilihat dari sisi penawaran wisata, pariwisata Yogyakarta dapat dikatakan lengkap, namun ternyata tidak semua objek wisata yang ada dikunjungi banyak wisatawan. Bahkan ada yang dikunjungi oleh beberapa orang saja, terutama objek-objek wisata budaya dan yang ditujukan untuk keluarga, misalnya museum batik, museum wayang dan beberapa museum lainnya. Itu menunjukkan bahwa ODTW tersebut tidak dapat memenuhi keinginan keluarga. Permasalahan yang ada terkait dengan masih lemahnya ODTW dalam mendukung rekreasi keluarga adalah selain jumlahnya terbatas, fasilitas dan kapasitas daya tampungnya pun terbatas. Selengkapnya, kelemahan tentang ODTW antara lain 1) Keterbatasan jumlah ODTW yang khusus untuk memenuhi kebutuhan anak dan keluarga ${ }^{9} ; 2$ )

\footnotetext{
9 Hal ini dapat dilihat dari sangat padatnya pengunjung
}

Adanya keterbatasan dalam pengembangan dari masing-masing objek wisata atau keterbatasan dalam berinovasi sehingga pengunjung tidak tertarik untuk berkunjung ulang, 3) Masih terbatasnya kemampuan pemandu di beberapa objek wisata keluarga sehingga pemandu tidak bisa memberikan panduan yang memuaskan pengunjung. ${ }^{10}$ Berbagai kelemahan itulah yang mempengaruhi pemikiran sebagian keluarga Yogyakarta untuk lebih memilih berekreasi di luar Yogyakarta.

\section{Penduduk dan Pilihan Tempat Rekreasi Keluarga}

Jumlah penduduk yang banyak dengan kondisi sosial-ekonomi yang baik disertai dengan kondisi sosial-budaya yang tengah mengalami perubahan ke arah modernisasi, menjadikan Yogyakarta sebagai daerah yang memiliki potensi besar sebagai pengirim wisatawan. Selama lima tahun (2008-2012) provinsi ini mengalami peningkatan penduduk sebesar 0,9-1,2 persen setiap tahun. Nilai ratarata anggota keluarga di Yogyakarta adalah 3,68 orang. Jika nilai rata-rata keluarga itu berlaku sama pada penduduk perkotaan dan perdesaan, setiap keluarga di Yogyakarta terdiri dari tiga sampai empat orang anggota

ODTW di Yogyakarta pada saat liburan sekolah yang seringkali membuat pengunjung tidak merasa nyaman saat berekreasi.

${ }^{10}$ Salah satu kesan negatif dari pengunjung objek wisata keluarga di Yogyakarta dapat dilihat di http://wisata. kompasiana.com/jalan-jalan/2013/08/26/kesan-pahitliburan-di-jogja-584098.html. 
Tabel 2.

Perkembangan dan Distribusi Penduduk Desa-Kota 2008-2012

\begin{tabular}{lccccccc}
\hline \multirow{2}{*}{ Tahun } & \multirow{2}{*}{ Penduduk (N) } & Keluarga (N) & $\begin{array}{c}\text { Rerata } \\
\text { Anggota }\end{array}$ & \multicolumn{2}{c}{ Perkotaan } & \multicolumn{2}{c}{ Perdesaan } \\
\cline { 5 - 8 } & & & Keluarga & $(\mathrm{N})$ & $(\%)$ & $(\mathrm{N})$ & $(\%)$ \\
\hline $\mathbf{2 0 0 8}$ & 3.419 .977 & 930.674 & 3,67 & 598.423 & 64,30 & 332.251 & 35,70 \\
$\mathbf{2 0 0 9}$ & 3.426 .637 & 951.102 & 3,60 & 613.271 & 64,48 & 337.831 & 35,52 \\
$\mathbf{2 0 1 0}$ & 3.457 .491 & 930.455 & 3,71 & 618.194 & 66,44 & 312.261 & 33,56 \\
$\mathbf{2 0 1 1}$ & 3.487 .325 & 929.236 & 3,75 & 616.641 & 66,36 & 312.595 & 33,64 \\
$\mathbf{2 0 1 2}$ & 3.514 .762 & 945.216 & 3,71 & 627.340 & 66,37 & 317.876 & 33,63 \\
\hline
\end{tabular}

Sumber: Olahan dari DIY dalam Angka 2013

Tabel 3.

Pilihan Tempat Rekreasi

\begin{tabular}{llcc}
\hline \multicolumn{1}{c}{ Daerah Tujuan Wisata } & Frekuensi & Persentase \\
\hline Yogyakarta & & 86 & 23,9 \\
& Jakarta & 62 & 16,7 \\
& JawaTengah & 57 & 15,9 \\
\multirow{4}{*}{ Luar Yogyakarta } & Jawa Timur & 52 & 13,9 \\
& Jawa Barat & 37 & 10,3 \\
& Bali & 35 & 9,7 \\
& Nusa Tenggara Barat & 19 & 5,3 \\
\multirow{4}{*}{ Luar Negeri } & Kepulauan Riau & 3 & 0,8 \\
& Singapura & 7 & 1,9 \\
Jumlah & Hongkong & 5 & 1,5 \\
\hline
\end{tabular}

Sumber: Data primer (2013)

keluarga, kemungkinan besar terdiri dari suami, isteri dengan satu atau dua anak. Angka kepadatan keluarga ini lebih rendah dari rata rata anggota keluarga di Indonesia sebesar 3,9 orang $^{11}$ (Tabel 2).

Besaran keluarga berpengaruh terhadap tingkat mobilitas keluarga dan beban ekonomi yang harus ditanggung keluarga ketika mereka melaksanakan rekreasi keluarga. Ketika keluarga di Yogyakarta berekreasi, beban ekonomi yang harus ditanggung oleh keluarga tidak terlalu besar. Jumlah anggota keluarga yang sedikit memungkinkan keluarga menjadi lebih mudah melaksanakan rekreasi bersama anggota keluarga. Hasil ini sesuai kajian Collins dan Tisdell (2002) yang menyebutkan bahwa peningkatan jumlah anggota keluarga memiliki efek negatif pada kondisi wisata.

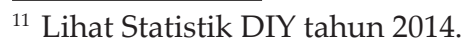

Tempat tinggal seseorang berpengaruh terhadap sikap dan perilakunya. Sebagian besar keluarga Yogyakarta tinggal di perkotaan (lebih dari 60 persen) dan kurang dari 40 persen tinggal di perdesaan. Kondisi ini berpengaruh pada gaya hidup dan pola kehidupan masyarakat. Banyaknya masyarakat yang tinggal di daerah perkotaan dan tingginya intensitas pengaruh media masa serta banyaknya wisatawan yang datang ke Yogyakarta menjadi salah satu faktor penjelas mengapa rekreasi keluarga berkembang di masyarakat Yogyakarta. Sebagian keluarga merencanakan sebelumnya, mulai dari waktu, tempat pelaksanaan dan jenis kegiatan atau hal-hal yang akan dinikmati untuk memperoleh kesenangan keluarga, terutama anak-anak. Mereka melaksanakan rekreasi pada saat liburan sekolah. Tempat yang dipilih adalah sebagai berikut (Tabel 3). 
Tabel 3 menunjukkan bahwa mereka memilih berekreasi di objek wisata di Yogyakarta (23.9 persen) dan luar Yogyakarta (76.1 persen). Jakarta menjadi pilihan utama, diikuti Jawa Tengah, Jawa Timur, Jawa Barat, Bali, Nusa Tenggara Barat dan terakhir Kepulauan Riau. Jakarta dipilih karena memiliki fasilitas rekreasi modern yang lebih baik dan lebih beragam. Pemilihan itu terkait dengan tujuan rekeasi keluarga, yakni memfasilitasi kebutuhan anak akan hiburan sekaligus untuk meningkatkan pengetahuan dan pengalaman. ${ }^{12}$ Rekreasi keluarga, karena ditujukan untuk memfasilitasi kepentingan anak-anak bersenang-senang, umumnya dilaksanakan pada satu tempat dengan waktu pelaksanaan yang relatif lama sehingga tidak mengambil banyak objek wisata dalam satu kegiatan rekreasi.

Pilihan berikutnya adalah Jawa Tengah dan Jawa Timur. Ini terkait dengan posisi geografis. Kedua provinsi itu merupakan provinsi yang lokasinya tidak terlalu jauh dari Yogyakarta, sehingga dari sisi jarak dan pengeluaran dana, tidak terlalu jauh beda dengan besarnya dana yang harus dikeluarkan untuk berekreasi di Yogyakarta.

\section{“Untuk rekreasi kemarin, kami ke Owabong di Purbalingga, anak-anak memilih tempat itu karena mereka belum pernah ke sana. Kami setujui saja mereka, saya kira juga tidak terlalu jauh, bisa dijangkau satu hari, sehingga biaya yang harus dikeluarkan juga tidak terlalu banyak" (Tri, PNS) $)^{13}$}

Selain pertimbangan jarak dan besarnya dana, ada pertimbangan lain mengapa mereka memilih luar Yogyakarta. Keluarga yang memilih Jakarta menyatakan Jakarta memiliki fasilitas hiburan yang lebih lengkap dan modern, misalnya fasilitas hiburan yang ada di Dunia Fantasi Ancol, yang baik untuk pembelajaran anak. Selain itu ada juga yang menyebutkan

\footnotetext{
${ }^{12}$ Wawancara dengan informan (Maya) pada tanggal 5 Oktober 2013.

${ }^{13}$ Wawancara dilaksanakan pada tanggal 2 Oktober 2013.
}

karena kondisi di Yogyakarta sendiri yang mendorong mereka memilih luar Yogyakarta. Mereka menyatakan Yogyakarta sudah kurang kondusif untuk berekreasi terutama jika saat musim liburan sekolah di akhir tahun. Pada saat itu, jalan banyak yang macet, terutama di kota dan jalan yang menghubungkan kota dengan objek wisata. Ada juga yang menyatakan memilih berekreasi di luar Yogyakarta karena sekalian mengunjungi keluarga.

\section{Posisi Strategis Yogyakarta}

Yogyakarta berada pada posisi strategis ${ }^{14}$, ini ditunjukkan oleh: 1) berada di tengah pulau Jawa, jarak dengan kota-kota lain di sekitarnya tidak terlalu jauh/relatif dekat; 2) berada dalam jejaring transportasi darat dan udara; 3 ) akses untuk menuju dan keluar dari provinsi ini sangat mudah karena tersedia jalan yang kondisinya baik untuk menuju kota-kota di sekitarnya. Jalan raya merupakan sarana pokok lalu lintas yang sangat diperlukan untuk transportasi dan kelancaran roda perekonomian. Fasilitas transportasi di Yogyakarta terdiri dari 4.863,786 $\mathrm{km}$ panjang jalan yang terbagi menjadi panjang jalan negara 3,98 persen, panjang jalan provinsi 12,94 persen, dan panjang jalan kabupaten/kota 83,08 persen. ${ }^{15}$

Jaringan jalan merupakan unsur utama keberadaan transportasi darat. Sistem transportasi darat di Yogyakarta meliputi jalur utama nasional, jalur utama provinsi dan jalur pengembangan. Jalur utama merupakan jalur yang sudah terbentuk dan merupakan bagian dari jalur transportasi nasional. Dilihat dari sisi perekonomian, jalur ini mempunyai peranan penting dalam memperkuat orientasi arus perdagangan yang berfokus ke tiga arah yaitu timur (Solo, Surabaya), utara (Semarang) dan barat (Purwokerto, Jakarta). Ada empat terminal di Yogyakarta sebagai

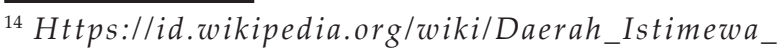
Yogyakarta.

${ }^{15}$ D.I. Yogyakarta dalam Angka 2000.
} 
Tabel 4.

Jumlah Kendaraan Bermotor yang Terdaftar di DIY (\%)

\begin{tabular}{|c|c|c|c|c|c|c|}
\hline \multirow[b]{2}{*}{ Tahun } & \multicolumn{5}{|c|}{ Tipe Kendaraan } & \multirow[b]{2}{*}{ Total } \\
\hline & $\begin{array}{c}\text { Mobil } \\
\text { penumpang }\end{array}$ & Bus & $\begin{array}{l}\text { Mobil } \\
\text { beban }\end{array}$ & $\begin{array}{l}\text { Kendaraan } \\
\text { khusus }\end{array}$ & $\begin{array}{c}\text { Sepeda } \\
\text { motor }\end{array}$ & \\
\hline 2008 & 8,49 & 0,85 & 3,11 & 0,04 & 87,51 & 1.276 .309 \\
\hline 2009 & 8,38 & 0,80 & 2,99 & - & 87,82 & 1.374 .202 \\
\hline 2010 & 8,34 & 0,74 & 2,83 & - & 88,05 & 1.488 .033 \\
\hline 2011 & 8,56 & 0,68 & 2,79 & 0,03 & 87,93 & 1.618 .457 \\
\hline 2012 & 8,70 & 0,63 & 2,77 & 0,03 & 87,87 & 1.749 .738 \\
\hline
\end{tabular}

Sumber: DIY dalam Angka 2013

tempat berhenti dan berangkat bus yang menghubungkan Yogyakarta dengan daerah lain, yakni Giwangan, Jombor, Imogiri, dan Wates.

Selama lima tahun (2008- 2012) jumlah kendaraan bermotor (mobil penumpang, mobil barang, bus, kendaraan khusus dan sepeda motor) meningkat signifikan (Tabel 4). Namun yang perlu diperhatikan, peningkatan terjadi hanya pada mobil penumpang sedangkan kendaraan bus mengalami penurunan dari tahun ke tahun, begitu juga dengan jenis kendaraan yang lain.

Tabel 4 menunjukkan bahwa minat masyarakat pada kendaraan umum dengan kapasitas banyak (bus) semakin menurun. Masyarakat lebih berminat pada mobil berpenumpang sedikit (mobil keluarga). Mobil jenis inilah yang lebih banyak digunakan sebagai alat transportasi ketika keluarga berekreasi. Peningkatan jumlah kendaraan bermotor memang tidak secara langsung menunjuk pada meningkatnya kegiatan rekreasi keluarga, tetapi itu berkaitan dengan peningkatan kesejahteraan dan mobilitas masyarakat Yogyakarta. Peningkatan jumlah mobil penumpang dapat menjadi petunjuk adanya peningkatan kebutuhan mobilitas penduduk. Fenomena itu ada kaitannya dengan kebiasaan masyarakat yang ketika berekreasi bersama keluarga, mereka lebih tertarik untuk menggunakan mobil pribadi dari pada menggunakan mobil umum. Sebagaimana tampak pada jawaban berikut:

\begin{abstract}
"Bagi kami kalau pergi bersama keluarga lebih enak jika menggunakan mobil pribadi, meskipun dengan menyewa, toh sekarang banyak rental mobil. Jika dengan mobil umum, akan kerepotan karena tidak praktis dan untuk menuju objek wisata tidak ada trayek khusus". (Tan, PNS) $)^{16}$
\end{abstract}

Sarana transportasi kereta api menjadi alternatif pilihan masyarakat yang akan menuju atau ke luar Yogyakarta. Ada dua stasiun di Yogyakarta, yakni stasiun Tugu dan Lempuyangan. Dua stasiun itu melayani tiga jalur pelayanan kereta api (Tabel 5).

\section{Tabel 5.}

\section{Jumlah Kereta Api yang Berhenti} di Stasiun Tugu (2013)

\begin{tabular}{lc}
\hline Jalur Pelayanan Kereta Api & Jumlah Kereta Api \\
Yogyakarta - Jakarta & 9 \\
Yogyakarta - Bandung & 6 \\
Yogyakarta - Surabaya / Malang & 8 \\
\hline
\end{tabular}

Sumber: PT KAI Daop VII Yogyakarta

Tabel 5 menunjukkan bahwa moda transportasi kereta api diminati oleh masyarakat. Dari beberapa informan, ditemukan alasan pemilihan kereta api sebagai alat transportasi, diantaranya adalah: 1) dibandingkan dengan menggunakan alat transportasi lain, biaya untuk naik kereta api lebih murah; 2) kereta api dianggap aman oleh masyarakat, angka kecelakaannya relatif rendah; 3) kereta api dianggap tepat waktu sehingga banyak yang

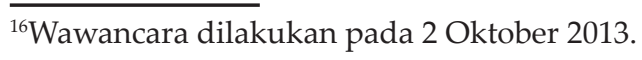


Tabel 6.

Jumlah Penumpang Kereta Api (2009 - 2012)

\begin{tabular}{lrrrrrrr}
\hline \multirow{2}{*}{ Tahun } & \multicolumn{2}{c}{ Eksekutif } & \multicolumn{2}{c}{ Bisnis } & \multicolumn{2}{c}{ Ekonomi } & \multirow{2}{*}{ Jumlah } \\
\cline { 2 - 7 } & $\mathrm{N}$ & $\%$ & $\mathrm{~N}$ & \multicolumn{1}{c}{$\%$} & $\mathrm{~N}$ & $\%$ & \\
\hline $\mathbf{2 0 0 9}$ & 487.691 & 16.08 & 1.858 .617 & 61.27 & 687.141 & 22.65 & 3.033 .449 \\
$\mathbf{2 0 1 0}$ & 708.470 & 21.34 & 781.112 & 23.53 & 1.829 .589 & 55.12 & 3.319 .171 \\
$\mathbf{2 0 1 1}$ & 878.838 & 25.43 & 718.224 & 20.78 & 1.858 .352 & 53.78 & 3.455 .414 \\
$\mathbf{2 0 1 2}$ & 697.261 & 26.32 & 612.806 & 23.13 & 1.338 .660 & 50.53 & 2.648 .727 \\
\hline
\end{tabular}

Sumber: DIY dalam Angka 2013

memilih untuk memakainya. Selama tiga tahun (2009- 2011), penumpang kereta api meningkat, sedangkan tahun 2012 menurun secara signifikan (Tabel 6).

Peningkatan jumlah penumpang kereta api menggambarkan tingginya mobilitas masyarakat Yogyakarta. Meskipun penumpang kereta api tidak bisa dikatakan sebagai pelaku rekreasi, tetapi sebagian dari mereka adalah masyarakat Yogyakarta yang akan berekreasi atau pulang dari rekreasi di luar Yogyakarta. Penumpang terbanyak terjadi pada bulan Januari dan Juli. Saat itu merupakan masa liburan panjang akhir sekolah. Pada saat itulah terjadi pergerakan orang, diantaranya adalah untuk melakukan perjalanan rekreasi.

Tabel di atas juga menunjukkan fenomena mobilitas penduduk, khususnya mengenai perkembangan moda transportasi kereta api. Tahun 2012 jumlah penumpang menurun 13,2 persen dari tahun sebelumnya. Penurunan ini ada kaitannya dengan kenaikan penumpang pesawat pada tahun yang sama menyusul pesatnya bisnis penerbangan sejak diberlakukannya deregulasi penerbangan pada tahun $1992^{17}$ (Tabel 7).

Tahun 2012 jumlah kedatangan pesawat di Bandara Adi Sucipto tercatat 17.585 kali, naik 16,16 persen dibanding tahun sebelumnya. Keberangkatan pesawat sebanyak 17.578 kali atau naik 16,40 persen dari tahun sebelumnya

\footnotetext{
17 Undang-Undang No. 15 Tahun 1992 tentang penerbangan merupakan salah satu tonggak deregulasi bisnis penerbangan di Indonesia. Jumlah perusahaan jasa penerbangan meningkat pesat dengan adanya Undang-Undang tersebut.
}

Tabel 7.

Penumpang Pesawat Udara

\begin{tabular}{ccccc}
\hline \multirow{2}{*}{ Tahun } & \multicolumn{2}{c}{ Pesawat } & \multicolumn{2}{c}{ Penumpang } \\
\cline { 2 - 5 } & Datang & Berangkat & Datang & Berangkat \\
\hline $\mathbf{2 0 0 9}$ & 18.080 & 18.070 & 1.580 .814 & 1.556 .003 \\
$\mathbf{2 0 1 0}$ & 22.379 & 22.385 & 1.723 .905 & 1.709 .827 \\
$\mathbf{2 0 1 1}$ & 15.138 & 15.102 & 2.025 .785 & 2.010 .662 \\
$\mathbf{2 0 1 2}$ & 17.585 & 17.578 & 2.377 .616 & 2.357 .005 \\
\hline
\end{tabular}

Sumber: Olahan data laporan PT Angkasa Pura II tahun 2010, 2011, 2012, 2013.

sebanyak 15.102 kali. Data itu menunjukkan banyaknya masyarakatyang melakukan mobilitas dengan menggunakan pesawat, diantaranya adalah untuk berekreasi di luar Yogyakarta.

\section{Pemahaman Masyarakat Yogyakarta Mengenai Waktu Luang, Libur dan Rekreasi,}

Berdasarkan hasil wawancara dengan 20 informan, diketahui bahwa pemahaman responden mengenai konsep rekreasi dikaitkan dengan waktu waktu luang, bahwa rekreasi adalah kegiatan yang menyenangkan dan dilaksanakan pada waktu luang. Ada dua persepsi mengenai waktu luang, yakni persepsi dari informan yang memiliki pekerjaan tetap dan dari informan yang tidak memiliki pekerjaan tetap. Bagi para pegawai tetap, waktu luang memiliki beragam makna, diantaranya 1) terjadi pada saat libur kerja dan cuti yang keberadaannya sudah ditentukan oleh tempat mereka bekerja/pihak eksternal dan keberadaannya bersifat rutin dalam periode yang tetap, yakni: mingguan, bulanan, maupun tahunan; 2) terjadi menjelang tidur malam; 3) 
terjadi pada saat istirahat kerja; 4) waktu yang menyenangkan karena mereka tidak harus bekerja tanpa meninggalkan kewajibannya; Selengkapnya pada pernyataaan berikut:

\begin{abstract}
"Waktu luang bagi saya adalah waktu saya selesai bekerja, baik pekerjaan kantor maupun pekerjaan di rumah. ...Di saat bekerja di kantor ada waktu istirahat, saat itu saya terbebas dari pekerjaan kantor, tetapi hanya sementara, jadi saya bisa memanfaatkannya sesuai keinginan saya. ... Ketika bekerja di rumah saya merasakan tidak ada waktu luang kecuali setelah malam menjelang tidur, saat itulah saya merasakan waktu luang" (Lis, PNS).18

"Bagi sayawaktu luang, hanya saya dapatkan pada saat saya libur dari kegiatan kantor, karenanya waktu luang sangat berharga bagi saya, sebagai kesempatanuntuk istirahat dan berkumpul dengan keluarga baik di rumah, maupun wisata ke beberapa tempat". (Ani, Swasta)..$^{19}$
\end{abstract}

Bagi mereka yang tidak memiliki pekerjaan tetap, yang waktu kerjanya tidak tetap, waktu luang lebih mereka pahami sebagai waktu yang: 1) terjadi pada saat mereka tidak bekerja karena tidak mendapatkan pekerjaan; 2) kurang menyenangkan sebab mereka tidak mendapatkan penghasilan karena tidak bekerja, informan tersebut tidak merasakan ada waktu luang yang dapat dimanfaatkan untuk berekreasi / berwisata dengan pemahaman seperti itu.

"Waktu luang bagi saya terjadi ketika
saya tidak bekerja, saya tidak mengerjakan
sesuatu untuk mencari penghasilan.
Kelihatannyaenak, tetapibagi saya keadaan
demikian menjadi beban karena saya tidak
menghasilkan uang untuk mencukupi
kebutuhan hidup" (SHN, tukang kayu). ${ }^{20}$

Kesimpulan yang dapat diambil dari ketiga jawaban tersebut adalah pemahaman mengenai waktu luang pada dikaitkan dengan waktu kerja tetapi memiliki makna yang berbeda bagi pemiliknya. Konsep waktu luang dan waktu

\footnotetext{
${ }^{18}$ Wawancara dilakukan pada tanggal 17 Oktober 2013.

${ }^{19}$ Wawancara dilakukan pada tanggal 12 Oktober 2013.

${ }^{20}$ Wawancara dilakukan pada tanggal 5 Nopember 2013.
}

kerja merupakan sebuah kontinum dari waktu yang dimiliki oleh manusia dalam menjalani kehidupannya. Waktu kerja menjadi yang utama, sedangkan sisanya merupakan waktu luang. Jadi waktu luang adalah sisa waktu yang dimiliki seseorang setelah menyelesaikan pekerjaan sebagai tanggung jawabnya. Jawaban itu sejalan dengan definisi residual waktu luang yang ditawarkan oleh Roberts (1999), yang menyatakan bahwa waktu luang adalah waktu yang tersisa dari pekerjaan dan kewajiban lain. Pemaknaan demikian itu dapat dikatakan mewakili sebuah pendekatan 'akal sehat' yang mendefinisikan waktu luang, sebagai entitas waktu di saat mereka selesai bekerja atau istirahat bekerja. Jadi bersifat sementara dan dapat digunakan sesuai dengan keinginan dan kepentingan diri yang bersangkutan, dimanfaatkan secara bebas bukan karena kehendak / tekanan pihak eksternal termasuk lingkungan sekitar yang bersangkutan.

Mengenai kapan waktu luang didapatkan oleh seseorang, disebutkan bahwa waktu luang terjadi atau diperoleh pada saat yang bersangkutan lepas dari tanggung jawab kepada pihak eksternal, yakni lembaga perusahaan, kantor tempat yang bersangkutan bekerja, waktu luang tetap merupakan waktu pribadi yang penggunaannya bebas sekehendak pemilik dan tidak dilembagakan. Informan lain menyatakan bahwa waktu luang dapat digunakan untuk melakukan pekerjaan rumah atau pekerjaan. Artinya, waktu luang bisa digunakan secara bebas untuk tujuan kerja, tetapi hanya jika itu adalah pilihan pribadi. Seorang informan membuat komentar berikut:

\footnotetext{
"Bagi saya,waktu luang adalah waktu yang bisa saya gunakan untuk acara bebas sekehendak saya. Acara bebas adalah kegiatan yang saya inginkan sendiri bukan karena memenuhi kepentingan orang lain. Saya biasanya memperbaiki rumah, mencuci mobil di waktu luang saya" (Pur, pegawai swasta) $)^{21}$
}

${ }^{21}$ Wawancara dilaksanakan pada tanggal 30 Oktober 
Ketika penulis menanyakan "Apa yang Anda pahami tentang liburan?" dan "Apa yang Anda lakukan pada saat liburan?", penulis memperoleh beragam pendapat dari beberapa informan dengan profesi yang berbeda, yakni petani, orang yang tidak memiliki pekerjaan tetap (serabutan) dan pegawai tetap suatu instansi. Petani menjawab bahwa dia tidak memiliki hari libur. Dia akan tidak pergi ke sawah untuk bekerja jika pada saat itu dia memang ada keperluan lain atau dia menganggap tidak perlu ke sawah karena tidak ada hal mendesak yang harus dikerjakan di sawah.

\begin{abstract}
"Saya sebagai petani tidak memiliki hari libur, saya bekerja berdasarkan keperluan. Jika saya anggap di sawah tidak ada yang harus dikerjakan (digarap) maka saya tidak akan ke sawah. Saya akan ke sawah jika ada yang harus dikerjakan, bahkan sampai berhari-hari tidak berhenti mengerjakan sawah kalau pekerjaan belum selesai. Jadi liburan saya berbeda dengan pegawai yang liburnya rutin tiap hari minggu atau Sabtu dan Minggu."(Bgy, petani).22
\end{abstract}

Substansi dan konsep hari libur oleh petani ini adalah tidak bekerja, tetapi waktu pelaksanaannya ditentukan oleh dia sendiri berdasarkan kepentingan pekerjaannya atau berdasarkan pertimbangan sosial kemasyarakatan. Misalnya ketika tetangganya mengadakan hajatan/gotong royong/ rewang ${ }^{23}$ atau kepentingan sosial lainnya, dia akan tidak pergi ke sawah untuk bekerja. Libur baginya tidak ditentukan oleh pihak lain, tetapi oleh pekerjaan dan pertimbangan pribadi. Saat itulah dia merasakan puas/ memperoleh kepuasan yang tidak perlu berekreasi / berwisata dengan mengunjungi objek wisata.

Tidak jauh berbeda dengan pendapat petani adalah pendapat yang dikemukakan

\section{3.}

22 Wawancara dilakukan pada tanggal 5 November 2013.

${ }^{23}$ Rewang adalah kata dalam bahasa Jawa yang berarti gotong royong/kerja sosial pada saat keluarga mengadakan hajatan. oleh pekerja bangunan mandiri / tukang. Dia memandang bahwa liburan itu juga semata tidak bekerja, bahkan memandang tidak bekerja itu akan merugikan mereka. Lain halnya jika tidak bekerja tetapi karena ada pertimbangan lain yang lebih penting. Sebagaimana dalam kutipan berikut:

"saya tidak memiliki hari kerja tetap, bisa
dikatakan bebas, bisa kerja bisa tidak.
Jadi saya tidak memiliki hari libur, saya
bekerja kalau ada orang memberi saya
pekerjaan, misalnya untuk mengurus atau
mengerjakan sesuatu. Kalau mendapatkan
pekerjaan, saya akan mengerjakannnya
setiap hari sampai selesai. Kadang-kadang
seminggu, bahkan lebih". Ketika tidak ada
orang yang memberi pekerjaan, saya tidak
bekerja. Tetapi itu bukan libur karena saat
itu saya tidak memperoleh penghasilan."
(Shd, Tukang kayu). ${ }^{24}$

Pendapat berbeda dikemukakan oleh pegawai tetap suatu instansi. Dia menjelaskan bahwa liburan adalah waktu dia tidak bekerja, tetapi tetap mendapatkan gaji. Baginya, waktu libur bisa digunakan untuk berbagai keperluan, termasuk melakukan perjalanan wisata bersama keluarganya, saat itu dia tidak harus bekerja sebagaimana tuntutan pekerjaannya, sebagaimana kutipan berikut:

\begin{abstract}
"Hari minggu adalah hari libur. Hari minggu bagi saya sangat berarti bagi saya. Hari itu saya dapat berkumpul dengan keluarga karena hari lainya, saya dan suami sibuk dati pulangnya sering sampai malam. Maka hari Minggu kami gunakan seefektif mungkin untuk keluarga. Biasanya kami pergi mengajak anak-anak ke tempat-tempat hiburan supaya mereka senang dan merasa diperhatikan orang tua". (Ani, Swasta) $)^{25}$
\end{abstract}

Simpulan dari tiga batasan tersebut, bagi pegawai tetap, liburan adalah pelembagaan waktu atau ketentuan terhadap waktu yang pada saat tersebut seseorang tidak diharuskan untuk bekerja atau melaksanakan komitmen yang

\footnotetext{
${ }^{24}$ Wawancara dilakukan pada tanggal 29 Oktober 2013. ${ }^{25}$ Wawancara dilakukan pada tanggal 12 Oktober 2013.
} 
menjadi tanggung jawab seseorang terhadap lembaga. Jadi liburan berasal bukan dari seorang individu, tetapi dari sebuah lembaga, misalnya; instansi pemerintah, perusahaan, sekolah dan lain-lain. Pada saat liburan, pegawai/pelajar tidak bekerja/melaksanakan kegiatan yang menjadi tanggung jawab tetapi bukan berarti menentang aturan lembaga sehingga mereka tetap mendapatkan hak-haknya yang diberikan oleh lembaga. Misalnya seseorang bekerja di perusahaan, pada saat liburan, dia tidak bekerja tetapi tetap mendapatkan gaji.

Jika dikaitkan dengan efek yang diterima oleh pelaku, dapat disimpulkan bahwa mereka akan merasa senang karena pada saat liburan, mereka bebas dari tanggung jawab tanpa kehilangan haknya. Ini berbeda dengan waktu luang. Jika dikatakan waktu luang sebagai waktu tidak bekerja, maka waktu luang itu bisa bernilai positif bagi yang mengalami, tetapi bisa juga bernilai negatif atau tidak menyenangkan, sedangkan liburan lebih banyak positifnya bagi yang menerima. Keadaan yang memiliki efek sama dengan liburan adalah cuti. Kesimpulan ini diperkuat dengan pendapat berikut:

"Liburan adalah waktu tidak bekerja.
Liburan bisa digunakan untukapa pun dan
tanpa rugi karena kita tidak ada kewajiban
yang harus dikerjakan. Liburan sudah
ditetapkan oleh pemerintah, jadikita tinggal
mengikuti saja. Cuti sama dengan liburan,
bedanya cuti itu ada karena permintaan kita.
$(Y o n, P N S)^{26}$

Pemahaman masyarakat Yogyakarta mengenai rekreasi keluarga, hakikatnya adalah sebuah keadaan atau kegiatan yang menjadi isi atau kandungan dari waktu luang atau liburan, akan disarikan dari hasil wawancara berikut:

"Di saat liburan, kami sekeluarga secara
rutin ke tempat-tempat tertentu untuk
berekreasi. Rekreasi keluarga, bagi kami
merupakan peristiwa yang sangat penting
dan menjadi agenda rutin. Hampir setiap
minggu, seusai ibadah di gereja, kami

${ }^{26}$ Wawancara dilakukan pada tanggal 20 Oktober 2013. melakukan wisata bersama anak-anak. Tempat wisata yang sering kami kunjungan adalah wahana bermain anak-anak, karena sesuai dengan usia anak-anak saya yang masih kanak-kanak. Rekreasi bersama menjadi peristiwa yang sangat penting, setelah enam hari, masing-masing anggota keluarga sibuk dengan kegiatan masingmasing. Rekreasi bersama menjadi peristiwa kebersamaan yang indah". (Ani, Swasta $)^{27}$ "Rekreasi keluarga sangat bagus untuk keharmonisan keluarga, dengan berbagai macam tingkat kesibukan dari masingmasing orang, berekreasi dengan keluarga adalah cara yang sangat baik untuk menjaga keluarga tetap harmonis". (Tan, PNS) ${ }^{28}$

Pemahaman waktu luang oleh masyarakat Yogyakarta sangat mirip dengan gagasan masyarakat Barat tentang waktu luang. Kesimpulan yang dapat diambil dari jawaban informan adalah keluarga di Yogyakarta memaknai rekreasi keluarga sebagai kegiatan bersama keluarga yang dilakukan pada saat waktu luang/liburan. Rekreasi keluarga dilaksanakan di luar tempat tinggal untuk membuat anakanak dapat merasakan kesenangan dan untuk meningkatkan keharmonisan keluarga.

\section{Kesimpulan}

Sebagian besar masyarakat Yogyakarta, terutama keluarga yang kepala keluarganya adalah pegawai tetap, telah menyadari adanya waktu kerja, waktu luang, waktu libur dan memahami akan pentingnya rekreasi keluarga sehingga mengagendakan rekreasi keluarga sebagai kegiatan yang perlu dilakukan. Sementara bagi yang bukan pekerja tetap, mereka tidak merasakan perlunya rekreasi keluarga. Mereka mengalami waktu luang, libur, dan waktu tidak bekerja tetapi itu semua tidak mereka rasakan sebagai kesempatan untuk berekreasi. Bagi mereka, waktu hidupnya adalah untuk bekerja. Mereka kadang melakukan rekreasi, tetapi itu karena dorongan sosial saja mengikuti lingkungan mereka.

\footnotetext{
${ }^{27}$ Wawancara dilakukan pada tanggal 12 Oktober 2013. ${ }^{28}$ Wawancara dilakukan pada tanggal 4 Oktober 2013.
} 
Perkembangan rekreasi keluarga yang terjadi di Yogyakarta dipengaruhi oleh faktor internal dan faktor eksternal. Faktor geografi, demografi dan sosial sangat berperan dalam hal ini. Lokasi yang strategis, banyaknya penduduk dan pemahaman masyarakat terhadap pentingnya berekreasi bersama keluarga masyarakat menjadi faktor yang mendorong pelaksanaan rekreasi keluarga. Berbagai kelemahan yang yang ada pada komponen pariwisata Yogyakarta mengkondisikan keluarga di Yogyakarta untuk lebih memilih berekreasi di luar Yogyakarta. Kondisi itu diperkuat dengan banyaknya penawaran wisata di luar Yogyakarta dan kemudahan aksesibilitas, fasilitas informasi dan komunikasi.

\section{Daftar Pustaka}

Collins, D., dan Tisdell, C. (2002). Age Related Lifecycles: Purpose Variations. Annals of Tourism Research, Volume 29 Issue 3, 801818.

Damanik, Janianton, dkk. (2012). Kegiatan Wisata dan Rekreasi Keluarga sebagai Sarana Pendidikan Cinta Tanah Air. Laporan Penelitian. Yogyakarta: Sekolah Pasca Sarjana UGM.

Elliot, J. (2010). Linking Family Leisure and Family Function: A Literature Review. US: University of Wisconsin-Stout. (Online). (http://www2. uwstout.edu/content/lib/ thesis/2010/2010elliottj.pdf.)

Freeman, P.; Zabriskie, R. (2003). Leisure and Family Functioning in Adoptive Families: Implications for Therapeutic Recreation. Therapeutic Recreation Journal. 37(1): 73-93.

Holman, T.; Epperson, A. (1984). Family and Leisure: A Review of the Literature with Research Recommendations. Journal of Leisure Research. 16: 277-294.

Horna, J. (1989). The Leisure Component of the Parental Role. Journal of Leisure Research. 21(2): 228-241.

Iwasaki, Y.; Havitz, M. (1998). A Path Analytic Model of the Relationships between
Involvement, Psychological Commitment and Loyalty. Journal of Leisure Research. 30(2): 256-280.

Kelly, J. (1996). Leisure. Needham, MA: Allyn \& Bacon.

Kelly, J. (1997). Changing Issues in LeisureFamily Research. Journal of Leisure Research. 29(1): 132-134.

Mannell, R.; Kleiber, D. (1997). A Social Psychology of Leisure. State Colledge, Pennsylvania: Venture Publishing Inc.

Nelson, A. \& Capple, M.; Adkins, D. (1995). Strengthening Families through Recreation: Family Outdoor Recreation Activities ProvideOpportunities for Skill Development and Socialization. Parks \& Recreation. 30 (6): 44-47.

Orthner, D. \& Mancini, J. (1991). Benefits of Leisure for Family Bonding. State College, PA: Venture Publishing Inc.

Schanzel, H., Yeoman I \& Backer E. (Eds). (2012). Family Tourism: Multidisciplinary Perspectives, Bristol: Channel View Publication.

Shaw, S. (1992). Dereifying Family Leisure: An Examination of Women's and Men's Everyday Experiences and Perceptions of Family Time. Leisure Sciences. 14: 271-286.

Shaw, S. M, and Dawson, D. (2001). Purposive Leisure: Examining Parental Discourses on Family Activities. Leisure Sciences, 23: 217231.

Smith, D. (1997). Strengthening Family Values in the Twenty-First Century: Home-centered recreation. Journal of Physical Education, Recreation \& Dance. 68 (8): 39-41.

Sutopo, dkk. (1999). Permintaan untuk Perjalanan Rekreasi bagi Wisatawan Nusantara: Studi Kasus Yogyakarta. Laporan Penelitian. Yogyakarta: Pusat Penelitian dan Pengembangan Pariwisata UGM.

Zabriskie, R., McCormick, B. (2001). The Influences of Family Leisure Patterns on Perceptions of Family Functioning. Family Relations. 5 (3): 281-289. 